\title{
A Robust Framework Based on Polymeric Octamolybdate Anions and Copper(II) Complexes of Tetradentate N-donor Ligands
}

\author{
Nour Dissem ${ }^{1}$, Beñat Artetxe ${ }^{2, *}(\mathbb{D})$, Leire San Felices ${ }^{3}$, Luis Lezama ${ }^{2}$, Amor Haddad $^{1,4}$ and \\ Juan M. Gutiérrez-Zorrilla ${ }^{2, *}$ \\ 1 Laboratoire de Matériaux, Cristallochimie et Thermodynamique Appliquée, Faculté des Sciences de Tunis, \\ Université de Tunis El Manar, 2092 Tunis, Tunisia; nour-dsm@hotmail.fr (N.D.); \\ amorhaddad08@gmail.com (A.H.) \\ 2 Departamento de Química Inorgánica, Facultad de Ciencia y Tecnología, Universidad del País Vasco \\ UPV/EHU, P.O. Box 644, 48080 Bilbao, Spain; luis.lezama@ehu.eus \\ 3 Servicios Generales de Investigación SGIker, Facultad de Ciencia y Tecnología, Universidad del País Vasco \\ UPV/EHU, P.O. Box 644, 48080 Bilbao, Spain; leire.sanfelices@ehu.eus \\ 4 Laboratoire des Matériaux et Cristallochimie, Institut Supérieur des Sciences Appliquées et Technologie, \\ 5111 Mahdia, Tunisia \\ * Correspondence: benat.artetxe@ehu.eus (B.A.); juanma.zorrilla@ehu.es (J.M.G.-Z.); Tel.: +34-94-601-5522
}

Received: 14 December 2017; Accepted: 4 January 2018; Published: 6 January 2018

\begin{abstract}
A new organic-inorganic compound based on octamolybdate building blocks and copper(II) complexes of tetradentate $\mathrm{N}$-donor ligands has been hydrothermally synthesized, namely $[\mathrm{Cu}(\text { cyclam })]_{2}\left[\mathrm{Mo}_{8} \mathrm{O}_{26}\right] \cdot 1.5 \mathrm{H}_{2} \mathrm{O}(\mathbf{1})$, (cyclam: 1,4,8,11-tetraazacyclotetradecane). Compound $\mathbf{1}$ has been chemically (elemental and thermal analyses), spectroscopically (infrared spectroscopy), and structurally (single crystal and powder X-ray diffraction) characterized. The crystal packing of 1 shows a covalent framework structure formed by $\left[\mathrm{Mo}_{8} \mathrm{O}_{26}\right]_{n}{ }^{4 n-}$ chains running along the 100 direction which are linked to each other through the coordination spheres of $\{\mathrm{Cu}(\mathrm{cyclam})\}^{2+}$ complexes leading to a three-dimensional open network. This structural assembly generates voids that can be described as a succession of cavities communicated through narrow bottlenecks with approximate cross section of $4 \times 7 \AA^{2}$ where the hydration water molecules are hosted. The robust open structure of 1 remains virtually unaltered upon thermal evacuation of guest solvent molecules at $130{ }^{\circ} \mathrm{C}$, resulting in the anhydrous phase $[\mathrm{Cu}(\text { cyclam })]_{2}\left[\mathrm{Mo}_{8} \mathrm{O}_{26}\right](\mathbf{1 a})$ with potentially accessible micropores as demonstrated by single-crystal $\mathrm{X}$-ray diffraction measurements. Electron paramagnetic resonance spectroscopy analysis of $\mathbf{1}$ has also been assessed.
\end{abstract}

Keywords: polyoxometalates; robust hybrid frameworks; crystal-to-crystal transformations

\section{Introduction}

Porous crystalline materials such as metal-organic frameworks (MOFs) and covalent organic frameworks (COFs) are of great interest due to their wide range of applications (gas separation and storage, ion exchange, host-guest chemistry) related to their permanent porous nature [1-5]. Particularly, the former field has entered a new stage where not only the porosity but also other physical properties are playing a key role in their potential application in current fields of interest like catalysis, magnetism or biomedicine [6-10]. However, this often requires the activation of the functional material through evacuation of solvent molecules. The presence of organic linkers results in frameworks with limited thermal and chemical stability that collapse when guest molecules are removed from their cavities. These difficulties could be a priori overcome by the incorporation 
of rigid metal clusters such as polyoxometalates (POMs) to the system. Moreover, recent work in MOF-chemistry have shown that small pores (that have been achieved by the interpenetration of metal-organic networks) and the use of small inorganic oxoanions (e.g., dichromate, molybdate) with electronegative atoms like oxygen pointing at the interior of the cavities, improve the selectivity of coordination frameworks towards small polarizable molecules like $\mathrm{CO}_{2}$ [11-13]. In view of this, the synthetic approach could be extended to larger oxo-units (or POM clusters), the crystal packing of which leads to relatively small pores within the structure.

POMs constitute a large family of anionic metal-oxo clusters with intrinsic multifunctional nature [14-16]. The POM-based porous crystalline solids have attracted great attention due to the possibility of combining the properties of the clusters (e.g., catalytic activity, magnetisms, luminesce) with those related to open-framework materials with high internal surface area [17-19]. Different synthetic methods have been developed to prepare POM-based open-frameworks including both supramolecular compounds and covalent extended lattices (POMOFs). The former strategy can be exemplified by the large family of ionic crystals formed by Keggin-type anions and bulky carboxylate-bridged trinuclear macrocations [20,21]. In contrast, the covalent approach involves i) the linkage of clusters directly by metal centres to result in purely inorganic open structures [22,23], or ii) the assembly of hybrid organic-inorganic frameworks in close analogy to classical MOFs. The latter requires organically derivatized POMs fragments that connect cationic metal nodes $[24,25]$ or metal-polysubstituted POM clusters that are linked through organic bridging ligands [26,27], and hence, it usually involves multistep synthetic work.

An alternative route that could take place in a one-pot synthesis is that in which POM clusters are connected through transition metal complexes bearing peripheral organic ligands. The ligands block equatorial coordination positions, allowing the linkage of contiguous POM units through the axial positions of the metal centers. In this regard, we have recently studied the reactivity of vanadates and tungstates toward copper(II) complexes of macrocyclic $\mathrm{N}$-donor cyclam $(1,4,8,11$-tetraazacyclotetradecane) ligands. In the case of vanadates, the synthetic systems have been shown to be $\mathrm{pH}$ dependent. The $[\mathrm{Cu}(\mathrm{cyclam})]\left[\{\mathrm{Cu}(\mathrm{cyclam})\}_{2}\left(\mathrm{~V}_{10} \mathrm{O}_{28}\right)\right] \cdot 10 \mathrm{H}_{2} \mathrm{O}$ supramolecular POMOF-like material was obtained at acidic $\mathrm{pH}$, the microporous structure of which displays empty channels accessible for the selective adsorption of $\mathrm{CO}_{2}$ over $\mathrm{N}_{2}$ [28] In contrast, basic conditions afforded the $\left[\{\mathrm{Cu}(\mathrm{cyclam})\}\left(\mathrm{VO}_{3}\right)_{2}\right] \cdot 5 \mathrm{H}_{2} \mathrm{O}$ three-dimensional open-framework hybrid. Its porosity drastically decreases upon a dehydration process that proceeds via two intermediate phases and hence, it is not useful for gas sorption applications [29]. On the other hand, the tungstate system represents a case where the dynamic three-dimensional covalent structure of $\left[\{\mathrm{Cu}(\mathrm{cyclam})\}_{3}\left(\mathrm{~W}_{7} \mathrm{O}_{24}\right)\right] \cdot 15.5 \mathrm{H}_{2} \mathrm{O}$ resulted in a microporous material with both $\mathrm{N}_{2}$ and $\mathrm{CO}_{2}$ gas sorption capacity upon full dehydration. Furthermore, a partially dehydrated phase was also isolated in the course of these studies [30]. In all cases, the crystallinity was fully retained throughout the thermal activation processes, which allows us to determine all the phases by single-crystal X-ray diffraction. Therefore, these systems can be included within the scarce examples of single-crystal-to-single-crystal (SCSC) transformations in POM-based compounds as indicated by a recent review [31]. SCSC transformations are currently a hot topic in crystal engineering because they provide the exact location of the atoms in a phase transition promoted by heat, light, or pressure and allows for correlating the structural changes with how a given property is modified upon the applied external stimuli.

Considering all the above, we are now interested in incorporating polyoxomolybdates to the system. The field of molybdates is one of the most active within the POM chemistry because of their interesting redox properties; some cluster can be reversible and easily reduced to blue species with retention of the POM skeleton. Addenda metals can also occupy a seven-coordinate polyhedron to lead to the development of several macrosized giant anions that represent some of the most spectacular POM clusters, including the ring-like $\left\{\mathrm{Mo}_{154}\right\}$, hollow icosahedral Keplerates or the "blue hedgehog" $\left\{\mathrm{Mo}_{368}\right\}$ [32-34]. However, the equilibria in water solution are dominated by small and simpler species like $\left[\mathrm{Mo}_{7} \mathrm{O}_{24}\right]^{6-}$ or $\left[\beta-\mathrm{Mo}_{8} \mathrm{O}_{26}\right]^{4-}$. In the case of heteropolyoxomolybdates, the use of Keggin or 
Wells-Dawson-type anions have been mainly limited to plenary structures due to the scarcity of available lacunary derivatives, in contrast to polyoxotungstates [14-16]. Alternatively, much work has been devoted to other clusters such as Anderson-Evans or Strandberg-type anions, and more specifically to the organic derivatization of these species $[35,36]$.

Herein, we report on the synthesis, crystal structure, thermal behavior, and electron paramagnetic resonance spectra of a new POMOF-like compound, namely, $\left[\mathrm{Cu}(\text { cyclam) }]_{2}\left[\mathrm{Mo}_{8} \mathrm{O}_{26}\right] \cdot 1.5 \mathrm{H}_{2} \mathrm{O}(\mathbf{1})\right.$. Compound $\mathbf{1}$ is built of polymeric octamolybdate chains covalently linked to $\{\mathrm{Cu}(\mathrm{cyclam})\}$ cationic complexes resulting in an open three-dimensional framework. Dehydration of $\mathbf{1}$ into 1a proceeds through a crystal-to-crystal transformation, and the structure remains virtually unaltered upon thermal evacuation of guest solvent molecules. Therefore, the robustness of the open hybrid skeleton and associated permanent porosity of $1 \mathrm{a}$ have been confirmed.

\section{Experimental Section}

\subsection{Materials and Methods}

All reagents were purchased from commercial sources and used without further purification. Carbon, nitrogen, and hydrogen were determined on a EuroVector EA 3000 CHNSO analyzer (EuroVector, Milan, Italy). Fourier transform infrared (FT-IR) spectra were recorded on KBr pellets using a Shimadzu FTIR-8400S spectrophotometer (Shimadzu, Kyoto, Japan). Thermogravimetric analyses (TGA) were carried out from room temperature to $600{ }^{\circ} \mathrm{C}$ at a rate of $5{ }^{\circ} \mathrm{C} \min ^{-1}$ on a Mettler-Toledo TGA/SDTA851 ${ }^{\mathrm{e}}$ thermobalance (Mettler Toledo, Greifensee, Switzerland) under a $70 \mathrm{~cm}^{3} \cdot \mathrm{min}^{-1}$ flow of synthetic air. Powder X-ray diffraction (PXRD) patterns were collected on a Bruker D8 Advance diffractometer operating at $40 \mathrm{kV} / 40 \mathrm{~mA}$ and equipped with $\mathrm{Cu} \mathrm{K} \alpha$ radiation $(\lambda=1.5418 \AA)$, a Vantec-1 PSD detector, an Anton Parr HTK2000 high-temperature furnace, and Pt sample holder. Variable temperature patterns were acquired from $30^{\circ} \mathrm{C}$ to $600^{\circ} \mathrm{C}$ every $10^{\circ} \mathrm{C}$. Electron Paramagnetic Resonance (EPR) spectra were recorded on Bruker ELEXSYS 500 (superhigh-Q resonator ER-4123-SHQ, Bruker, Karlsruhe, Germany) and Bruker EMX (ER-510-QT resonator, Bruker, Karlsruhe, Germany ) continuous wave spectrometers for Q- and X-bands, respectively.

\subsection{Synthesis of $[\mathrm{Cu}(\mathrm{cyclam})]_{2}\left[\mathrm{Mo}_{8} \mathrm{O}_{26}\right] \cdot 1.5 \mathrm{H}_{2} \mathrm{O}(\mathbf{1})$ and $[\mathrm{Cu}(\mathrm{cyclam})]_{2}\left[\mathrm{Mo}_{8} \mathrm{O}_{26}\right](\mathbf{1 a})$}

A mixture of $\mathrm{H}_{3}\left[\mathrm{PMo}_{12} \mathrm{O}_{40}\right] \cdot 4 \mathrm{H}_{2} \mathrm{O}(0.18 \mathrm{~g} ; 0.1 \mathrm{mmol}), \mathrm{CuCl}_{2} \cdot 2 \mathrm{H}_{2} \mathrm{O}(0.17 \mathrm{~g}, 1.0 \mathrm{mmol})$ and cyclam ( $0.04 \mathrm{~g} ; 0.2 \mathrm{mmol})$ in $1 \mathrm{M} \mathrm{NaOAc} / \mathrm{HOAc}$ buffer solution $(15 \mathrm{~mL})$ was stirred for $1 \mathrm{~h}$, transferred to a $50 \mathrm{~mL}$ Teflon-lined autoclave, and kept at $140{ }^{\circ} \mathrm{C}$ for $72 \mathrm{~h}$ under autogenous pressure. After cooling the reaction mixture to room temperature for $48 \mathrm{~h}$, dark brown crystals suitable for single-crystal X-ray diffraction were obtained. Crystals of $\mathbf{1}$ were washed with water and separated manually under the optical microscope. Yield: $35 \mathrm{mg}, 15 \%$ based on Mo. Elemental Analyses (\%): Calcd. (found) for $\mathrm{C}_{20} \mathrm{H}_{51} \mathrm{Cu}_{2} \mathrm{Mo}_{8} \mathrm{~N}_{8} \mathrm{O}_{27.5}$ : C, 13.88 (13.74); H, 2.97 (2.85); N, 6.48 (6.40). IR (cm $\left.{ }^{-1}\right)$ : 3489 (m), 3227 (vs), 3126 (vs), $2968(\mathrm{~s}), 2871(\mathrm{~s}), 1627(\mathrm{~m}), 1456(\mathrm{~m}), 1429(\mathrm{~m}), 1292(\mathrm{w}), 1244(\mathrm{w}), 1093(\mathrm{~m}), 1008(\mathrm{~m}), 939(\mathrm{~s})$, $900(\mathrm{~m}), 850$ (vs), $800(\mathrm{~m}), 700(\mathrm{~m}), 615(\mathrm{vs}), 518(\mathrm{~m}), 480(\mathrm{w}), 460(\mathrm{w}), 410(\mathrm{~m})$. The anhydrous phase 1a was obtained upon heating single crystals of 1 in an oven for $1 \mathrm{~h}$ at $140{ }^{\circ} \mathrm{C}$.

\subsection{X-ray Crystallography}

Crystallographic data for compounds $\mathbf{1}$ and $\mathbf{1 a}$ are summarized in Table 1. Intensity data were collected at 100(2) K on an Agilent Technologies SuperNova diffractometer (Santa Clara, CA, USA) equipped with an Eos CCD detector, mirror-monochromated Mo K $\alpha$ radiation $(\lambda=0.71073 \AA)$ and an Oxford Cryostream 700 PLUS (Oxford Cryosystems Ltd., Oxford, UK) temperature device. Data collections, unit cell determinations, intensity data integrations, routine corrections for Lorentz and polarization effects, and multi-scan (1) or analytical absorption corrections with face indexing (1a) were performed using the CrysAlisPro software package (Agilent Technologies UK Ltd., Oxford, UK) [37]. The structures were solved using OLEX2 (OlexSys Ltd. in Durham University, Durham, 
UK) [38] and refined by full matrix least-squares with SHELXL-97 (University of Göttingen, Göttingen, Germany) [39]. Final geometrical calculations were carried out with PLATON (Utrecht University, Utrecht, The Netherlands) [40] as integrated in WinGX (University of Glasgow, Glasgow, UK) [41]. Bond valence sum (BVS) calculations [42] were carried out using the BVSumCalc program (courtesy of Dr. M. H. Dickman), whereas SHAPE (Universitat de Barcelona, Barcelona, Spain) [43] was used to perform continuous shape measures. Thermal vibrations were treated anisotropically for all non-H atoms in both compounds and hydrogen atoms were placed in calculated positions using standard SHELXL parameters. The population factor for the water molecule was initially refined without restriction and fixed to 0.75 in the last refinement cycle. The measured crystal for $\mathbf{1 a}$ is a non-merohedrical twin of two components (principal component: 78\%). The refinement has been carried out with a hklf5 file taking into account only one component. CCDC-1810974 (1) and 1810975 (1a) contain the supplementary crystallographic data for this paper. These data can be obtained free of charge from The Cambridge Crystallographic Data Centre via www.ccdc.cam.ac.uk/data_request/cif.

Table 1. Crystallographic data for $\mathbf{1}$ and $\mathbf{1 a}$.

\begin{tabular}{|c|c|c|}
\hline Parameters & 1 & $1 \mathbf{a}$ \\
\hline Formula & $\mathrm{C}_{20} \mathrm{H}_{51} \mathrm{Cu}_{2} \mathrm{Mo}_{8} \mathrm{~N}_{8} \mathrm{O}_{27.5}$ & $\mathrm{C}_{20} \mathrm{H}_{48} \mathrm{Cu}_{2} \mathrm{Mo}_{8} \mathrm{~N}_{8} \mathrm{O}_{26}$ \\
\hline $\mathrm{FW}\left(\mathrm{g} \mathrm{mol}^{-1}\right)$ & 1738.3 & 1711.26 \\
\hline Crystal System & Triclinic & Triclinic \\
\hline Space Group & P-1 & P-1 \\
\hline$a(\AA)$ & $9.6366(5)$ & $9.6460(5)$ \\
\hline$b(\AA)$ & $10.3864(6)$ & $10.3541(7)$ \\
\hline$c(\AA)$ & $12.3411(6)$ & $12.2349(8)$ \\
\hline$\alpha\left(^{\circ}\right)$ & $73.222(4)$ & $73.882(6)$ \\
\hline$\beta\left(^{\circ}\right)$ & $83.260(4)$ & $84.087(4)$ \\
\hline$\gamma\left({ }^{\circ}\right)$ & $76.865(5)$ & $76.875(5)$ \\
\hline$V\left(\AA^{3}\right)$ & 1149.92(11) & $1142.22(12)$ \\
\hline Z & 1 & 1 \\
\hline$\rho_{\text {calcd }}\left(\mathrm{g} \mathrm{cm}^{-3}\right)$ & 2.510 & 2.488 \\
\hline$\mu\left(\mathrm{mm}^{-1}\right)$ & 3.102 & 3.118 \\
\hline Collected Reflections & 7539 & 8043 \\
\hline Unique Reflections $\left(R_{\text {int }}\right)$ & $4062(0.035)$ & $4362(0.031)$ \\
\hline Observed Reflections $[I>2 \sigma(I)]$ & 3394 & 3527 \\
\hline Parameters & 304 & 293 \\
\hline$R(F)^{\mathrm{a}}[I>2 \sigma(I)]$ & 0.038 & 0.026 \\
\hline$w R\left(F^{2}\right)^{\mathrm{a}}$ [all data] & 0.104 & 0.065 \\
\hline GoF & 1.059 & 0.950 \\
\hline
\end{tabular}

\section{Results and Discussion}

\subsection{Synthesis and Infrared Spectroscopy}

Reactions aiming the preparation of $[\mathrm{Cu}(\text { cyclam })]^{2+} /\left[\mathrm{PMo}_{12} \mathrm{O}_{40}\right]^{3-}$ hybrids were initially performed in open bench conditions using acetate/acetic acid buffered media. No identifiable solid product was obtained after testing different temperatures (room temperature, $60{ }^{\circ} \mathrm{C}$, reflux conditions) and stoichiometric ratios. However, the hydrothermal synthesis involving equimolar amounts of phosphomolybdic acid and cyclam ligand and a great excess of a copper(II) salt in a buffered NaOAc/HAc media resulted in crystals of compound $\mathbf{1}$. The success of the reaction was firstly identified by infrared spectroscopy (FT-IR). As shown by the FT-IR spectrum of $\mathbf{1}$ when compared with that of the $\mathrm{H}_{3} \mathrm{PMo}_{12} \mathrm{O}_{40}$ precursor (Figure 1), the stretching vibrational band $v(\mathrm{P}-\mathrm{O})$ at $1064 \mathrm{~cm}^{-1}$ was absent in 1, indicating that the reaction promotes the decomposition and subsequent rearrangement of the POM precursor to lead to a isopolyoxomolybdate anion. In addition, major modifications in terms of position and relative intensity took place in the $700-100 \mathrm{~cm}^{-1}$ region for the bands arising 
from $\mathrm{Mo}-\mathrm{O}_{\mathrm{t}}$ and $\mathrm{Mo}-\mathrm{O}_{\mathrm{b}}$-Mo bonds ( $\mathrm{t}=$ terminal, $\mathrm{b}=$ bridging). The organic region above $1000 \mathrm{~cm}^{-1}$ in $\mathbf{1}$ was dominated by signals of medium-weak intensity associated with $\mathrm{C}-\mathrm{N}, \mathrm{C}-\mathrm{C}, \mathrm{C}-\mathrm{H}$ bonds that confirmed the presence of the cyclam ligand. Consequently, in order to optimize the reaction conditions, additional experiments were performed under similar conditions, but using a molybdate source, i.e. $\mathrm{Na}_{2} \mathrm{MoO}_{4} \cdot 4 \mathrm{H}_{2} \mathrm{O}$ or $\left(\mathrm{NH}_{4}\right)_{6} \mathrm{Mo}_{7} \mathrm{O}_{24} \cdot 4 \mathrm{H}_{2} \mathrm{O}$, instead of the $\mathrm{POM}$ precursor. Unfortunately, no identifiable crystalline product was obtained in the course of these studies.

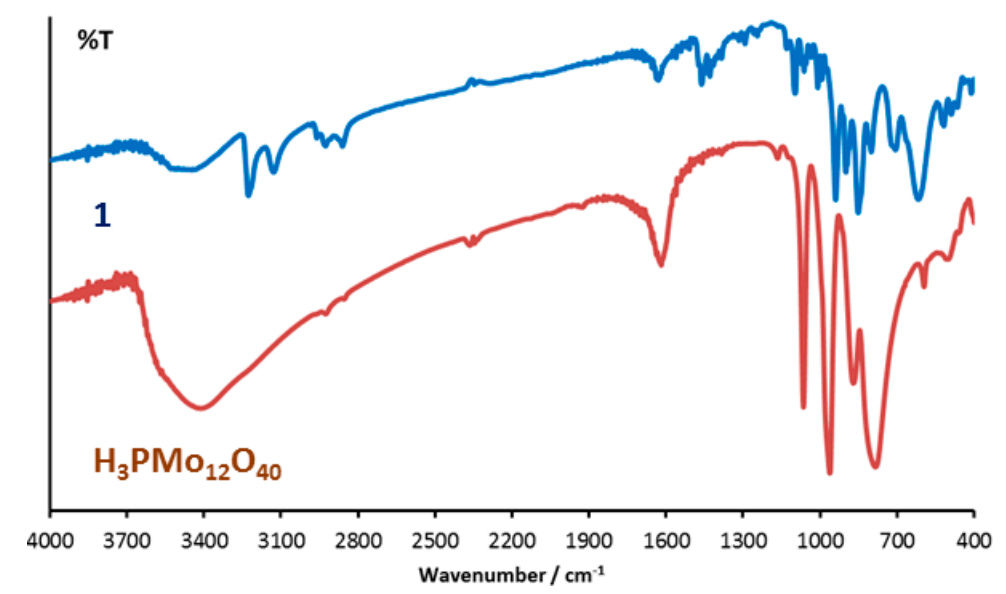

Figure 1. Fourier transform-infra-red (FT-IR) spectrum of 1 compared with that of the $\mathrm{H}_{3} \mathrm{PMo}_{12} \mathrm{O}_{40}$ polyoxometalate (POM) precursor.

\subsection{Thermostructural Analysis}

The thermostructural behavior of $\mathbf{1}$ was investigated by a combination of thermogravimetric (TGA) and variable temperature powder X-ray diffraction (PXRD) analyses. The TGA curve (Figure 2a) shows that the thermal decomposition proceeded via three well-differentiated steps. The initial continuous mass loss below $130{ }^{\circ} \mathrm{C}$ corresponded to the dehydration process and implies the release of 1.5 water molecules [\% mass, calc. (found): 1.55 (1.62)]. Total dehydration leads to the anhydrous phase (1a), which is thermally stable up to ca. $290{ }^{\circ} \mathrm{C}$. The relatively long thermal stability range for 1a suggests its robust nature. Above this temperature an exothermic mass loss takes place that corresponds to the combustion of two cyclam ligands per octamolybdate unit [\%mass, calc. (found) for $2 \times \mathrm{C}_{10} \mathrm{H}_{24} \mathrm{~N}_{4}: 23.05$ (22.74)] and the breakdown of the POM framework. The final residue is obtained at ca. $510{ }^{\circ} \mathrm{C}$ and it accounts for the $75.64 \%$ of the initial mass (\%mass, calc. for $\mathrm{Cu}_{2} \mathrm{Mo}_{8} \mathrm{O}_{26} 75.40$ ).

In order to investigate thermally triggered structural transformations that 1 could undergo, variable temperature PXRD experiments were carried out. As mentioned before, two different behaviors have been observed in related hybrid compounds based on $\{\mathrm{Cu}(\mathrm{cyclam})\}^{2+}$ units previously reported by some of us [28-30]. In the case of robust frameworks, they remained virtually unaltered upon thermal evacuation of guest solvent molecules, whereas dynamic structures undergo crystalline phase transitions promoted by the thermal stimulus. Experimental diffraction patterns registered between $30^{\circ} \mathrm{C}$ and $600{ }^{\circ} \mathrm{C}$ (Figure $2 \mathrm{~b}$ ) showed that 1 retained its crystallinity upon dehydration up to temperatures in the $100-120^{\circ} \mathrm{C}$ range. Total dehydration did not imply substantial variation in neither the positions nor the intensities of the diffraction maxima when comparing the PXRD pattern of the anhydrous phase 1a with that of the hydrated 1 . No modification was observed in the two most intense diffraction maxima located at the low $2 \theta$ region $\left(7-10^{\circ}\right)$. However, subtle modifications could be noticed upon close inspection of weak intensity peaks in the $2 \theta=20-35^{\circ}$ domain. More specifically, the group of maxima centered at $22.5^{\circ}$ and $24^{\circ}$ appeared to shift slightly, whereas the intensity of those located at $26.3^{\circ}, 28.4^{\circ}$ and $33.3^{\circ}$ underwent small but perceptible variations (Figure 2c). This fact indicated that dehydration did not result in drastic structural changes or changes in the cell parameters of 1 . The crystalline phase $1 \mathrm{a}$ was stable from $130^{\circ} \mathrm{C}$ up to $290^{\circ} \mathrm{C}$, as expected from the above-mentioned 
thermal studies. Signs of a high temperature phase were appreciable ca. $310^{\circ} \mathrm{C}$ but unfortunately, we were not able to perform its reliable identification. A new crystalline phase started appearing at temperatures above $360^{\circ} \mathrm{C}$ and it reached complete formation at $430{ }^{\circ} \mathrm{C}$, which corresponded to the final residue of the thermal decomposition. At this point, the pattern was defined enough for being identified as a mixture of the orthorhombic $\mathrm{Pbnm} \mathrm{MoO}_{3}$ [44] and the triclinic $P-1$ phase of $\mathrm{CuMoO}_{4}[45]$ in an approximate 6:2 ratio.
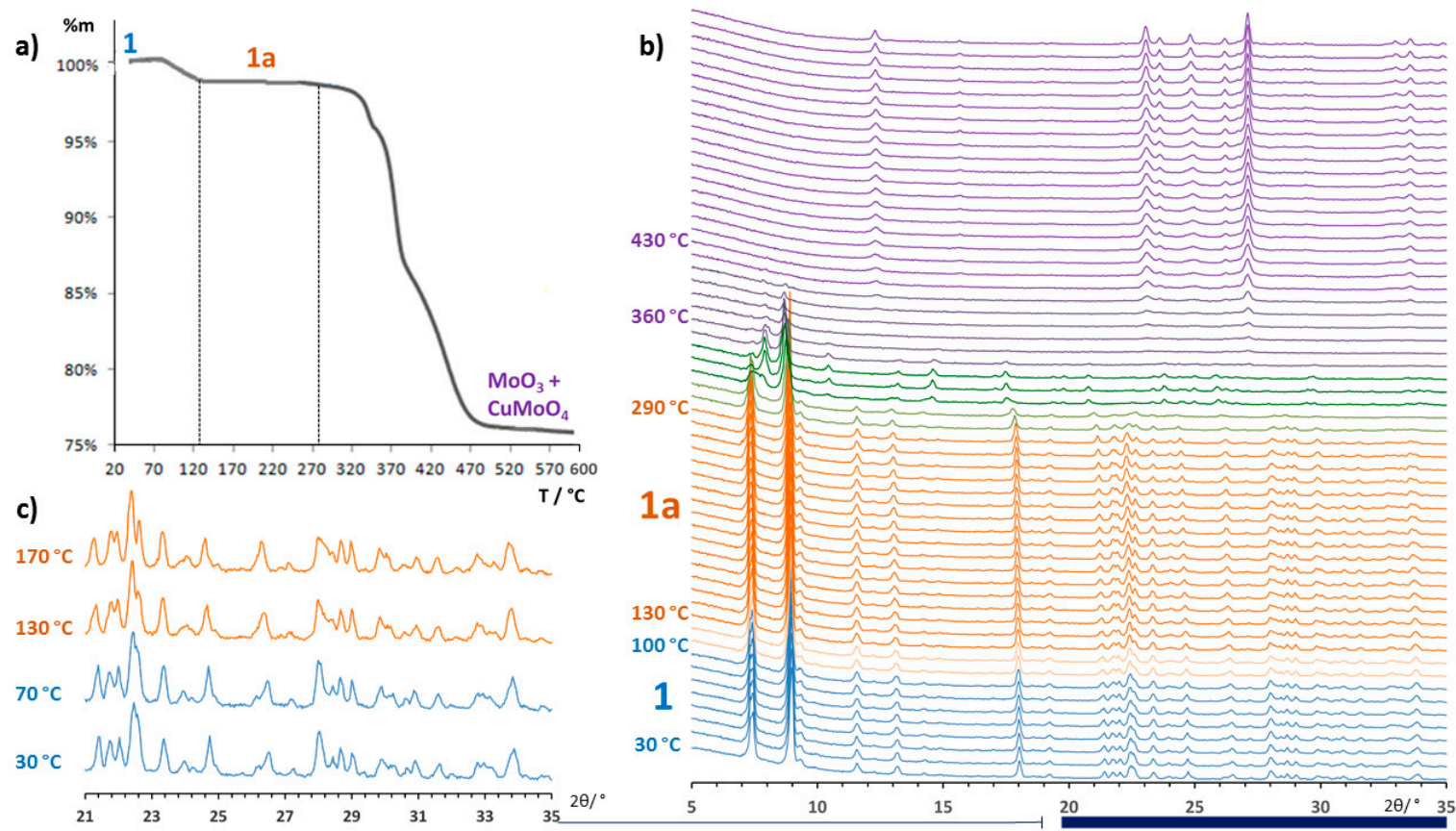

Figure 2. (a) Thermogravimetric (TGA) curve of $\mathbf{1}$; (b) variable temperature powder X-ray diffraction (PXRD) studies for 1 ; (c) expanded region of the PXRD patterns highlighting subtle differences between 1 and $1 a$.

\subsection{Crystal Structures of $\mathbf{1}$ and $\mathbf{1 a}$}

Compound 1 crystalized in the triclinic, $P-1$ space group and its asymmetric unit contained one-half of the $\left\{\mathrm{Mo}_{8} \mathrm{O}_{26}\right\}^{4-}$ unit, two crystallographically independent, centrosymmetric $\{\mathrm{Cu} \text { (cyclam) }\}^{2+}$ complexes and one water molecule of hydration with a population factor of $75 \%$ (Figure 3). The $\left\{\mathrm{Mo}_{8} \mathrm{O}_{26}\right\}^{4-}$ species belonged to a polymeric structure formed by $\gamma$-octamolybdate subunits. It is worth highlighting the large variety of octamolybdate-type clusters that can be found in the literature since crystal structures of as much as nine isomeric forms namely $\alpha, \beta, \gamma, \delta, \varepsilon, \zeta, \eta, \theta, \iota$ and the partially reduced $\chi$ have been reported to date [46-50]. The $\left[\gamma-\mathrm{Mo}_{8} \mathrm{O}_{26}\right]^{4-}$ anion consists of six octahedral $\left\{\mathrm{MoO}_{6}\right\}$ and two five-coordinated $\left\{\mathrm{MoO}_{5}\right\}$, resulting in two $\left\{\mathrm{Mo}_{4} \mathrm{O}_{15}\right\}$ rhomb-like tetramers linked to each other through edge sharing. Because of the presence of five-coordinated molybdenum centers, $\gamma$-octamolybdate anions can be organically derivatized with alcoxo groups [51,52], and tend to further condense in acidic conditions with analogous clusters, leading to polymeric chains based on the $\gamma-\mathrm{Mo}_{8} \mathrm{O}_{28}$ subunit. The connection usually takes place by sharing one or two corners with adjacent units that result in $\left\{\mathrm{Mo}_{8} \mathrm{O}_{27}\right\}_{n}$ and $\left\{\mathrm{Mo}_{8} \mathrm{O}_{26}\right\}_{n}$ like chains, respectively and less frequently via edge sharing. Furthermore, depending on the type of oxygen atoms (axial, $\mathrm{O}_{a}$; or equatorial $\mathrm{O}_{e}$ ) taking part in the linkage head-to-tail and side-to-side geometries can be distinguished [53] (Figure 4). The $\left\{\mathrm{Mo}_{8} \mathrm{O}_{26}\right\}_{n}$ polymers in $\mathbf{1}$ were constituted by $\gamma$-octamolybdate subunits linked to each other by sharing two corners in a head-to-tail fashion. In addition, Bond Valence Sum (BVS) calculations confirmed the absence of any protonation site within the POM anion [42]. All the structural evidences of $\left\{\mathrm{Mo}_{8} \mathrm{O}_{26}\right\}_{n}$ type chains found in the Cambridge Structural Database [54] are compiled in Table 2. 


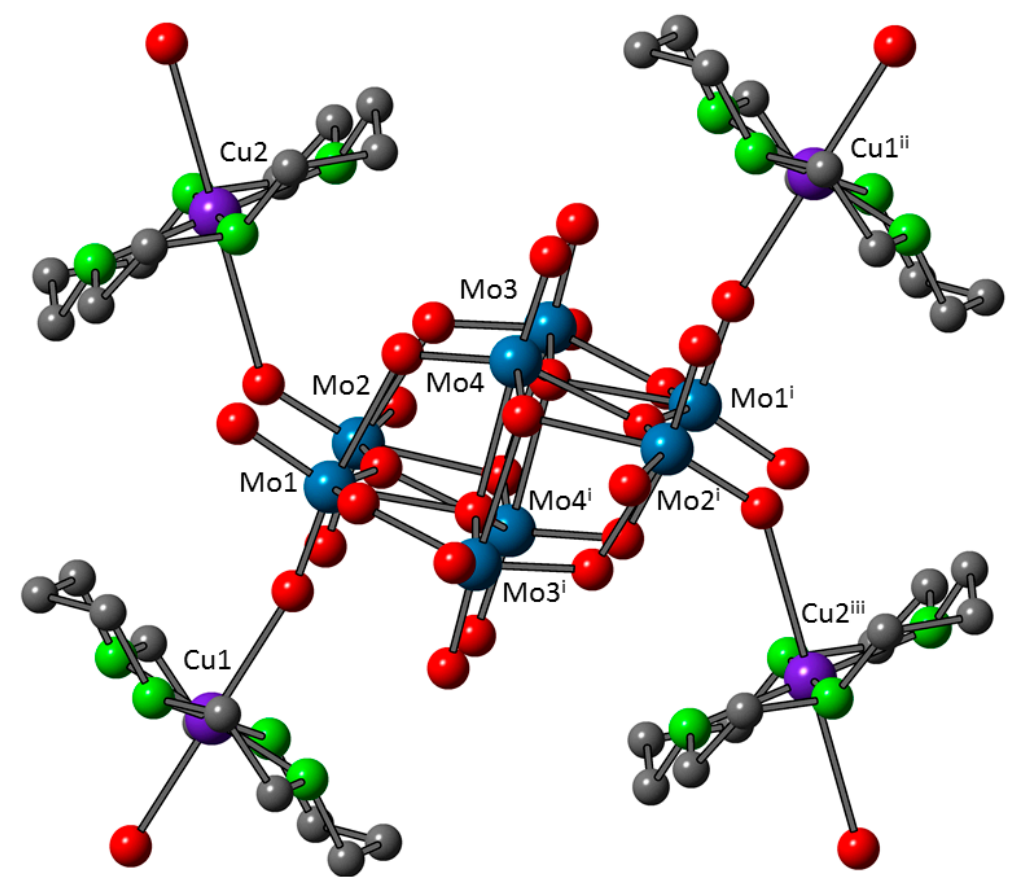

Figure 3. Ball \& stick representation of the $\left\{\gamma-\mathrm{Mo}_{8} \mathrm{O}_{26}\right\}^{4-}$ unit and bridging $\{\mathrm{Cu}(\mathrm{cyclam})\}^{2+}$ complexes in 1, together with atom labeling. Hydrogen atoms and water molecules are omitted for clarity. Color code: Mo, blue; $\mathrm{Cu}$, violet; $\mathrm{O}$, red; $\mathrm{N}$, green; $\mathrm{C}$, grey. Symmetry codes: (i) $2-x, 2-y, 1-z$; (ii) $x, y, 1+z$; (iii) $1+x, 1+y, z$.

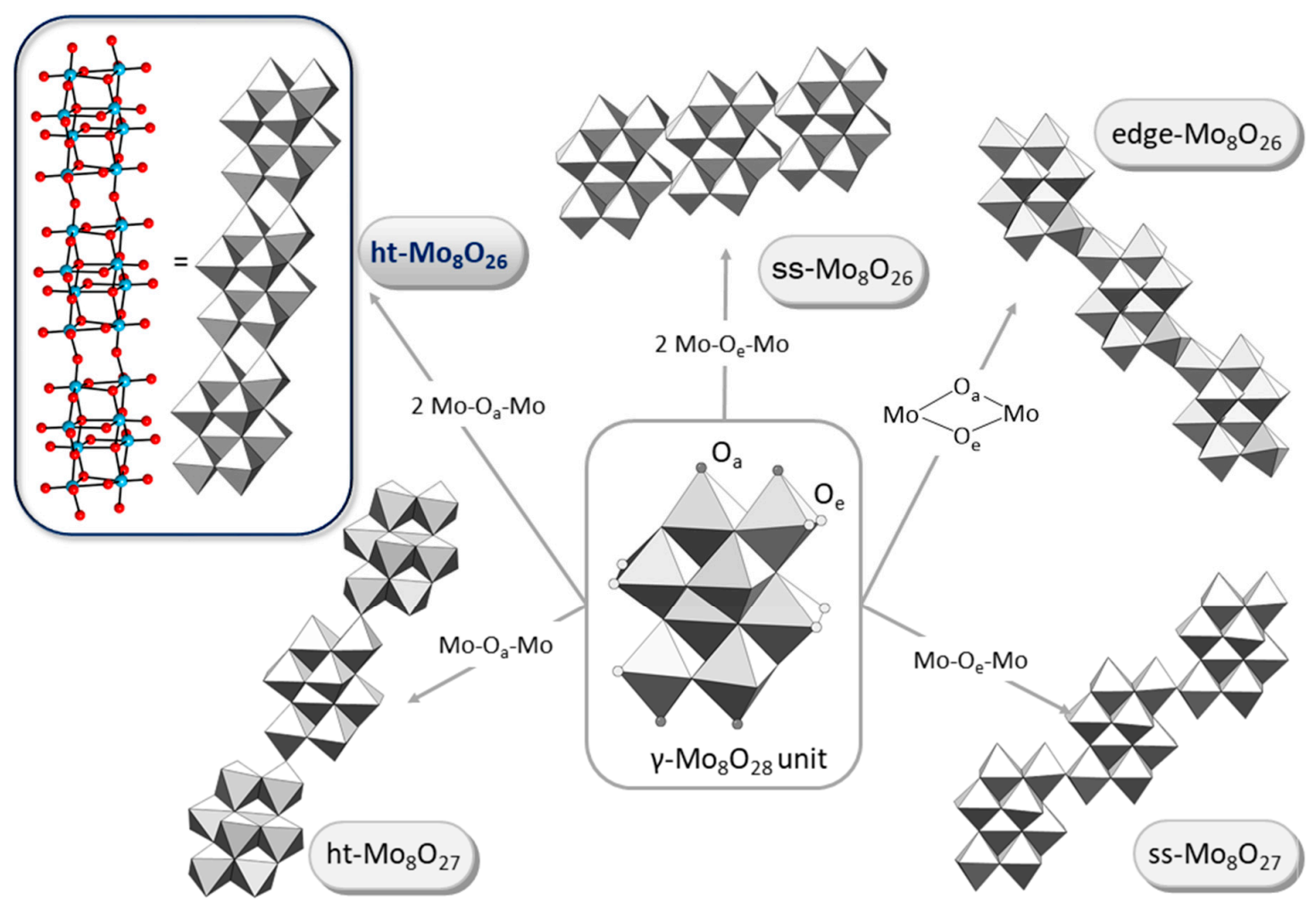

Figure 4. Schematic representation of the polymeric entities based on the $\gamma-\mathrm{Mo}_{8} \mathrm{O}_{28}$ subunit. Highlighted head-to-tail $\left\{\mathrm{Mo}_{8} \mathrm{O}_{26}\right\}_{\mathrm{n}}$ chains found in 1. (Code: ht = head-to-tail; ss = side-to-side; $\mathrm{O}_{a}=$ axial oxygen atom; $\mathrm{O}_{e}=$ equatorial oxygen atom). 
Table 2. List of compounds containing $\left\{\mathrm{Mo}_{8} \mathrm{O}_{26}\right\}_{\mathrm{n}}{ }^{4 \mathrm{n}-}$ chains.

\begin{tabular}{|c|c|c|c|}
\hline Formula & Ref. & Formula & Ref. \\
\hline ht & & ss & \\
\hline$\left(\mathrm{H}_{3} \mathrm{tib}\right)_{2}\left[\mathrm{Co} .\left(\mathrm{H}_{2} \mathrm{O}\right)_{2}\left(\mathrm{Mo}_{8} \mathrm{O}_{26}\right)_{2}\right] \cdot 2 \mathrm{H}_{2} \mathrm{O}$ & [55] & {$\left[\mathrm{Ag}_{2}(\operatorname{trz})_{2}\right]_{2}\left[\mathrm{Mo}_{8} \mathrm{O}_{26}\right]$} & [56] \\
\hline$\left(\mathrm{H}_{4} \mathrm{bbpbm}\right)\left[\mathrm{Mo}_{8} \mathrm{O}_{26}\right] \cdot 2 \mathrm{H}_{2} \mathrm{O}$ & [57] & {$\left[\mathrm{Cu}(3-\mathrm{dpye})\left(\mathrm{Mo}_{8} \mathrm{O}_{26}\right)\left(\mathrm{H}_{2} \mathrm{O}\right)_{8}\right] \cdot 2 \mathrm{H}_{2} \mathrm{O}$} & [58] \\
\hline$\left[\mathrm{Cu}(\mathrm{die})_{2}\left(\mathrm{Mo}_{8} \mathrm{O}_{26}\right)\right]$ & [59] & {$\left[\mathrm{Cu}\left(\mathrm{H}_{2} \mathrm{bbpbm}\right)\left(\mathrm{Mo}_{8} \mathrm{O}_{26}\right)\right] \cdot 3 \mathrm{H}_{2} \mathrm{O}$} & [57] \\
\hline$\left(\mathrm{H}_{2} \text { dmeen }\right)_{2}\left[\mathrm{Mo}_{8} \mathrm{O}_{26}\right]$ & {$[60]$} & $\left(\mathrm{H}_{2} \text { dmen }\right)_{2}\left[\mathrm{Mo}_{8} \mathrm{O}_{26}\right] \cdot 2 \mathrm{H}_{2} \mathrm{O}$ & [61] \\
\hline edge & & $\left(\mathrm{H}_{2} \mathrm{dmpin}\right)_{2}\left[\mathrm{MeO}_{2}\right.$ & [62] \\
\hline$\left\{\left[\mathrm{Ni}\left(\mathrm{H}_{2} \mathrm{bpim}\right)_{3}\left(\mathrm{Mo}_{8} \mathrm{O}_{26}\right)_{2}\left(\mathrm{H}_{2} \mathrm{O}\right)_{2}\right] \cdot 2 \mathrm{H}_{2} \mathrm{O}\right.$ & [63] & $\left(\mathrm{H}_{2} \mathrm{dabco}\right)_{2}\left[\mathrm{Mo}_{8} \mathrm{O}_{26}\right] \cdot 4 \mathrm{H}_{2} \mathrm{O}$ & [64] \\
\hline$(\mathrm{bmim})_{2}\left[\mathrm{Mo}_{8} \mathrm{O}_{26}\right]$ & [59] & $\left(\mathrm{H}_{2} \text { dabco }\right)_{2}\left[\mathrm{Mo}_{8} \mathrm{O}_{26}\right] \cdot 4.66 \mathrm{H}_{2} \mathrm{O}$ & [64] \\
\hline
\end{tabular}

Abbreviations: 3-dpye $=N, N^{\prime}$-bis(3-pyridinecarboxamide)-1,2-ethane; bbpbm $=1,1^{\prime}$-(1,4-butanediyl)bis[2-(4-pyridyl) benzimidazole]; bmim =1,1'-bis(1-methylimidazolium)methylene; bpim =1,1'-bis(pyridin-3-ylmethyl)-2,2'-biimidazole; dabco $=1,4$-diazabicyclo[2.2.2]octane; die = 1,2-diimidazoloethane; dmeen $=N, N^{\prime}$-dimethyl-N-ethylethylenediamine; dmen $=\mathrm{N}, \mathrm{N}$-dimethylethylenediamine; dmpip = 1,4-dimethylpiperazine; tib = 1,3,5-tris(imidazol-1-ylmethyl)benzene); trz $=1,2,4$-triazole.

The two crystallographically independent $\{\mathrm{Cu}(\text { cyclam })\}^{2+}$ complexes $(\mathrm{Cu} 1$ and $\mathrm{Cu} 2)$ play the role of linking moieties between octamolybdate chains resulting in a three-dimensional covalent framework. The $\mathrm{CuN}_{4} \mathrm{O}_{2}$ coordination spheres around both copper ions can be best described as distorted octahedral, in which the $\mathrm{N}$ atoms of the cyclam ligand form the equatorial plane and terminal $\mathrm{O}$ atoms from adjacent $\mathrm{POM}$-chains occupy the centrosymetrically related axial positions. Whereas $\mathrm{Cu}-\mathrm{N}$ and $\mathrm{Cu}-\mathrm{O}_{\mathrm{POM}}$ bond lengths for $\mathrm{Cu} 1$ are in the expected range (around $2.0 \AA$ and $2.3 \AA$, respectively) for an octahedron with a slight Jahn-Teller distortion, the axial elongation in $\mathrm{Cu} 2$ is much more pronounced with $\mathrm{Cu}-\mathrm{O}_{\mathrm{POM}}$ bond lengths approaching semi-coordination $(2.7 \AA)$. These observations are in good agreement with the continuous shape measurement (CSM) calculations [43] carried out for the six-coordinated centers in comparison to the ideal octahedral $\left(\mathrm{O}_{h}\right)$ geometry (Table 3). According to the literature, transition metal complexes of the cyclam ligand can adopt up to five different geometrical isomers (from trans-I to trans-V) depending on the ligand conformation and, more specifically, on whether the $\mathrm{N}-\mathrm{H}$ bonds are located above or below the $\mathrm{MN}_{4}$ plane [65]. Both $\mathrm{Cu} 1$ and $\mathrm{Cu} 2$ display the so-called trans-III configuration in which two $\mathrm{N}-\mathrm{H}$ bonds point to one side of the $\mathrm{CuN}_{4}$ equatorial plane and the other two $\mathrm{N}-\mathrm{H}$ bonds point to the opposite side. This is in perfect agreement with previous reports in the literature, which have shown that the most favorable configuration of a $\{\mathrm{Cu}(\mathrm{cyclam})\}$ complex with an octahedral geometry is indeed the trans-III one [66].

The crystal packing of $\mathbf{1}$ consist in a three-dimensional covalent open-framework constructed by hybrid layers of $\left\{\mathrm{Mo}_{8} \mathrm{O}_{26}\right\}_{n}{ }^{4 n-}$ anions running along the crystallographic $x$ axis linked by the $\mathrm{Cu} 1$ bridging moieties along the [1] direction. These hybrid layers parallel to the $x z$ plane are further connected through $\mathrm{Cu} 2$ complexes along the [10] direction, in such way that each polymeric anion results linked to the four neighboring chains. Two different grafting sites can be identified for the two complexes: inner (for Cu1) and bridging (for $\mathrm{Cu} 2$ ) $\left\{\mathrm{MoO}_{6}\right\}$ moieties between $\mathrm{Mo}_{8} \mathrm{O}_{26}$ subunits (Figure 3). This arrangement leads to the formation of hybrid grids, the stacking of which results in water accessible voids (Figure $5 \mathrm{a}, \mathrm{c}$ ). The covalent hybrid framework is reinforced by $\mathrm{C}-\mathrm{H} \cdots \mathrm{O}$ and $\mathrm{N}-\mathrm{H} \cdots \mathrm{O}-\mathrm{type}$ hydrogen bonds established between cyclam ligands and POM oxygen atoms as well as hydration water molecules (Table 4). At the first glance, the structural assembly seems to generate square-like channels parallel to the $x$ axis where the hydration water molecules are hosted. However, the representation of the solvent accessible space shows that these channels are disrupted and could be best described as a succession of cavities communicated through narrow bottlenecks (Figure $5 b, d$ ). Thus, the wall of each void is delimited by rings of four octamolybdate units belonging to different chains and four $\{\mathrm{Cu}($ cyclam $)\}]^{2+}$ complexes in alternate fashion with an approximate cross section of about $4.0 \times 6.8 \AA^{2}$ (distances $\mathrm{C} 6 \mathrm{~A} \cdots \mathrm{C} 6 \mathrm{~A}$ and $\mathrm{C} 5 \mathrm{~B} \cdots \mathrm{C} 5 \mathrm{~B}$ ). The total solvent accessible volume of the voids centered at $(1 / 2,1 / 2,0)$ is $80 \AA^{3}$ per unit cell, which only accounts for the $6.9 \%$ of the cell volume as calculated using PLATON [40]. 
Table 3. Bond lengths ( $\mathrm{\AA})$ of the copper(II) centers in $\mathbf{1}$ and $\mathbf{1 a}$.

\begin{tabular}{ccc}
\hline & $\mathbf{1}$ & $\mathbf{1 a}$ \\
\hline Cu1 & & \\
Cu1-N1A & $2.011(8)$ & $2.008(8)$ \\
Cu1-N1A ${ }^{\text {i }}$ & $2.011(8)$ & $2.008(8)$ \\
Cu1-N4A & $2.026(8)$ & $2.036(8)$ \\
Cu1-N4A ${ }^{\text {i }}$ & $2.026(8)$ & $2.036(8)$ \\
Cu1-O1L & $2.299(5)$ & $2.287(6)$ \\
Cu1-O1L ${ }^{\text {i }}$ & $2.299(5)$ & $2.287(6)$ \\
CSM (Oh $)$ & 0.562 & 0.477 \\
Cu2 & & \\
Cu2-N1B & $2.000(5)$ & $2.007(8)$ \\
Cu2-N1B ii & $2.000(5)$ & $2.007(8)$ \\
Cu2-N4B & $2.013(6)$ & $2.007(6)$ \\
Cu2-N4B ii & $2.013(6)$ & $2.007(6)$ \\
Cu2-O2L & $2.725(8)$ & $2.742(12)$ \\
Cu2-O2L ${ }^{\text {ii }}$ & $2.725(8)$ & $2.742(12)$ \\
CSM (O $\left.{ }_{h}\right)$ & 2.442 & 2.569 \\
\hline
\end{tabular}

Symmetry codes: (i) $-x,-y,-z$; (ii) $1-x, 1-y, 1-z$.

a)



b)

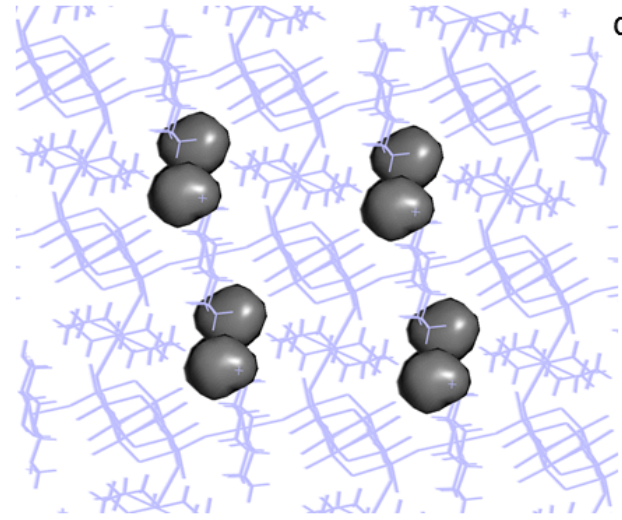

c)

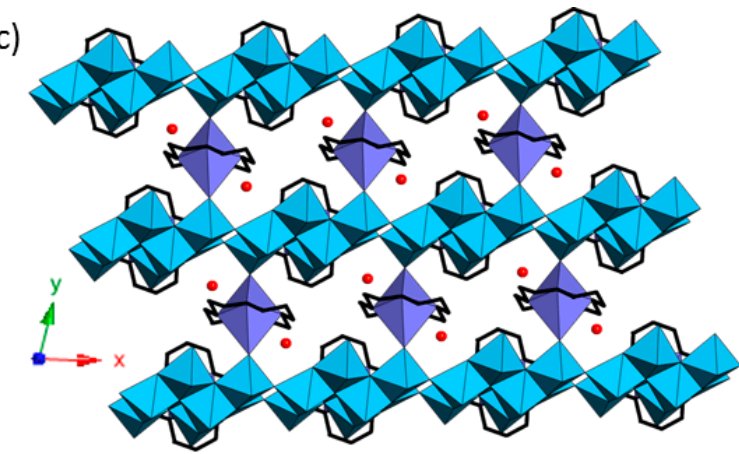

d)

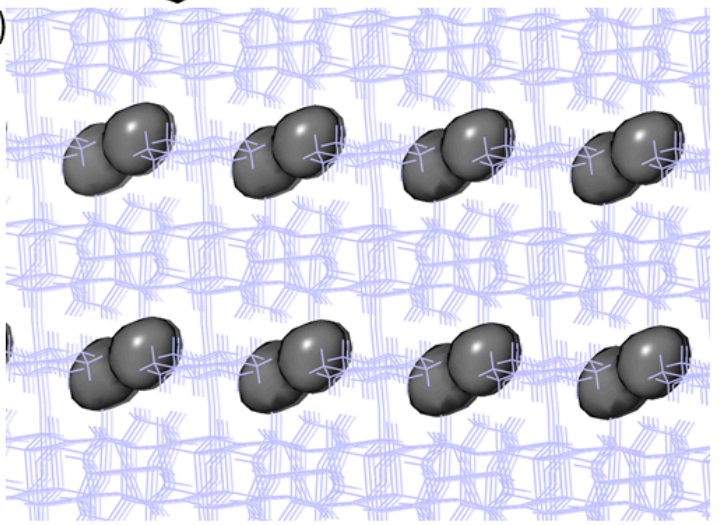

Figure 5. (a) Crystal packing of $\mathbf{1}$ viewed along the crystallographic $x$ axis and (b) surface representation of the solvent accessible voids. (c) Crystal packing of $\mathbf{1}$ viewed along the crystallographic $z$ axis and (d) surface representation of the solvent accessible voids. Hydrogen atoms are omitted for clarity. Color code: same as in Figure 3.

According to variable temperature PXRD results, $\mathbf{1}$ preserves its crystallinity upon thermal evacuation of guest solvent molecules without any significant structural modification. In view of this, we decided to perform single crystal XRD experiments on crystals of $\mathbf{1}$ heated at $130{ }^{\circ} \mathrm{C}$ to determine minor changes that could take place or whether the three-dimensional assembly in 1 remains completely unaltered in the anhydrous 1a. Crystals of $\mathbf{1}$ preserved their integrity upon thermal treatment, so that we were able to perform a full data acquisition for 1a. Nevertheless, 
although five crystals from different batches were tested, all of them were twinned (for refinement details see experimental section). As expected from PXRD studies, the hybrid framework in 1a proved to be virtually identical to that of the parent 1 . Cell parameters and the arrangement of the constituent building blocks, including bond lengths and geometrical distortion belonging to $\mathrm{Cu}$ (II) coordination spheres (Table 3), remained almost invariable. The release of water molecules hardly produces small changes in the hydrogen-bonding network that can be viewed in the shortening (about $0.1 \AA)$ of contacts implying POM oxygen atoms $\left(\mathrm{O}_{2}\right.$ and $\left.\mathrm{O}_{4}\right)$ that have been involved in $\mathrm{O}_{\mathrm{w}}-\mathrm{H} \cdots \mathrm{O}_{\mathrm{POM}}$ interactions in the parent hydrated phase 1 . The total solvent accessible volume remains almost constant as well ( $75 \AA^{3}$ per unit cell, $6.6 \%$ of the cell volume). The absence of any important change upon dehydration confirms the robustness of the hybrid open-framework, and indicates that the lattice water molecules in $\mathbf{1}$ do not play any structural role. Since the solvent accessible volume of $80 \AA^{3}$ in the hydrated phase 1 barely corresponds to two water molecules considering the $40 \AA^{3}$ occupied per each entity according to PLATON and the minimal contraction that it undergoes upon thermal activation, the applicability of the hybrid material for gas storage has been completely dismissed. However, the permanent microporous nature of 1a could be potentially exploited for the separation of small neutral molecules (e.g., $\mathrm{H}_{2}$ ), which is considered a hot topic of a key interest from industrial and environmental viewpoints.

Table 4. Bond lengths ( $\mathrm{A})$ of the copper(II) centers in $\mathbf{1}$ and $\mathbf{1 a}$.

\begin{tabular}{|c|c|c|}
\hline & 1 & $1 a$ \\
\hline $\mathrm{N} 1 \mathrm{~A} \cdots \mathrm{O}^{\mathrm{i}}$ & $2.915(8)$ & $2.901(8)$ \\
\hline $\mathrm{N} 4 \mathrm{~A} \cdots \mathrm{O} 4^{\mathrm{i}}$ & $3.494(7)$ & $3.401(8)$ \\
\hline N1B …O1 & $3.089(7)$ & $3.068(8)$ \\
\hline $\mathrm{N} 1 \mathrm{~B} \cdots \mathrm{O} 14$ & $3.416(6)$ & $3.403(7)$ \\
\hline $\mathrm{N} 4 \mathrm{~B} \cdots \mathrm{O} 23$ ii & $2.845(7)$ & $2.827(8)$ \\
\hline $\mathrm{C} 2 \mathrm{~A} \cdots \mathrm{O} 2$ & $3.324(9)$ & $3.240(9)$ \\
\hline C5A $\cdots \mathrm{O} 1 w$ & $3.366(13)$ & \\
\hline $\mathrm{C} 6 \mathrm{~A} \cdots \mathrm{O} 4{ }^{\mathrm{iii}}$ & $3.498(8)$ & $3.394(9)$ \\
\hline C7A $\cdots \mathrm{O} 1$ & $3.513(9)$ & $3.486(8)$ \\
\hline $\mathrm{C} 2 \mathrm{~B} \cdots \mathrm{O} 13^{\mathrm{ii}}$ & $3.154(8)$ & $3.151(8)$ \\
\hline C3B $\cdots \mathrm{O} 1$ & $3.133(9)$ & $3.139(9)$ \\
\hline $\mathrm{C} 5 \mathrm{~B} \cdots \mathrm{O} 2 \mathrm{~L}$ & $3.299(8)$ & $3.287(9)$ \\
\hline $\mathrm{C} 6 \mathrm{~B} \cdots \mathrm{O} 14$ & & $3.349(7)$ \\
\hline $\mathrm{C} 7 \mathrm{~B} \ldots \mathrm{O} 13^{\text {iv }}$ & $3.273(9)$ & $3.251(10)$ \\
\hline $\mathrm{O} 1 \mathrm{w} \cdots \mathrm{O} 2 \mathrm{v}$ & $2.919(10)$ & \\
\hline $\mathrm{O} 1 \mathrm{w} \cdots \mathrm{O} 4$ & $2.982(10)$ & \\
\hline
\end{tabular}

\subsection{Electron Paramagnetic Resonance Spectroscopy}

The X- $(v=9.39 \mathrm{GHz})$ and Q-band $(v=33.90 \mathrm{GHz})$ EPR spectra were recorded at room temperature on a powdered sample of $\mathbf{1}$ (Figure 6). Both spectra display the characteristic signal of a $g$ tensor with rhombic symmetry, accompanied by the absence of any kind of hyperfine structure. The resonances could be reasonably good fitted to a single Lorentzian signal whose $g$ values compare well with those expected for axially elongated octahedral $\mathrm{Cu}^{\mathrm{II}} \mathrm{N}_{4} \mathrm{O}_{2}$ chromophores [67] (Table 5).

Taking into account the structural features of $\mathbf{1}$, the absence of hyperfine splitting together with the presence of a single signal in a system showing two crystallographically independent $\mathrm{Cu}^{\mathrm{II}}$ centers indicate that paramagnetic ions are not magnetically isolated in the structure; i.e., it suggests that the spectra originate from an exchange tensor with contributions from both magnetic centers, rather than from a molecular tensor. In good agreement with this hypothesis, $G$ values (as defined by Hathaway [68]) corresponding to both spectra are considerably smaller than 4 (X-band: 2.5; Q-band: 2.7). The fact that all the ions of the same type are magnetically equivalent allows the good resolution of the spectra even if the coordination environment of the two inequivalent $\mathrm{Cu}^{\mathrm{II}}$ centers is 
different. The observed value for $g_{1}$ is smaller than that expected for any of the two individual species due to the perpendicular relative orientation of the main axis for both chromophores. Similarly, the $g_{3}$ is greater than 2.04 as expected for a $d_{x}{ }^{2}-y^{2}$ type ground state centers. Finally, it is worth noting that the spectral resolution is similar for the two applied frequencies (X-and Q-band). This fact implies that the magnitude of the magnetic exchange has to be greater than the energy gap between the states arising from the Zeeman splitting in Q-band, that is, around $1 \mathrm{~cm}^{-1}$.
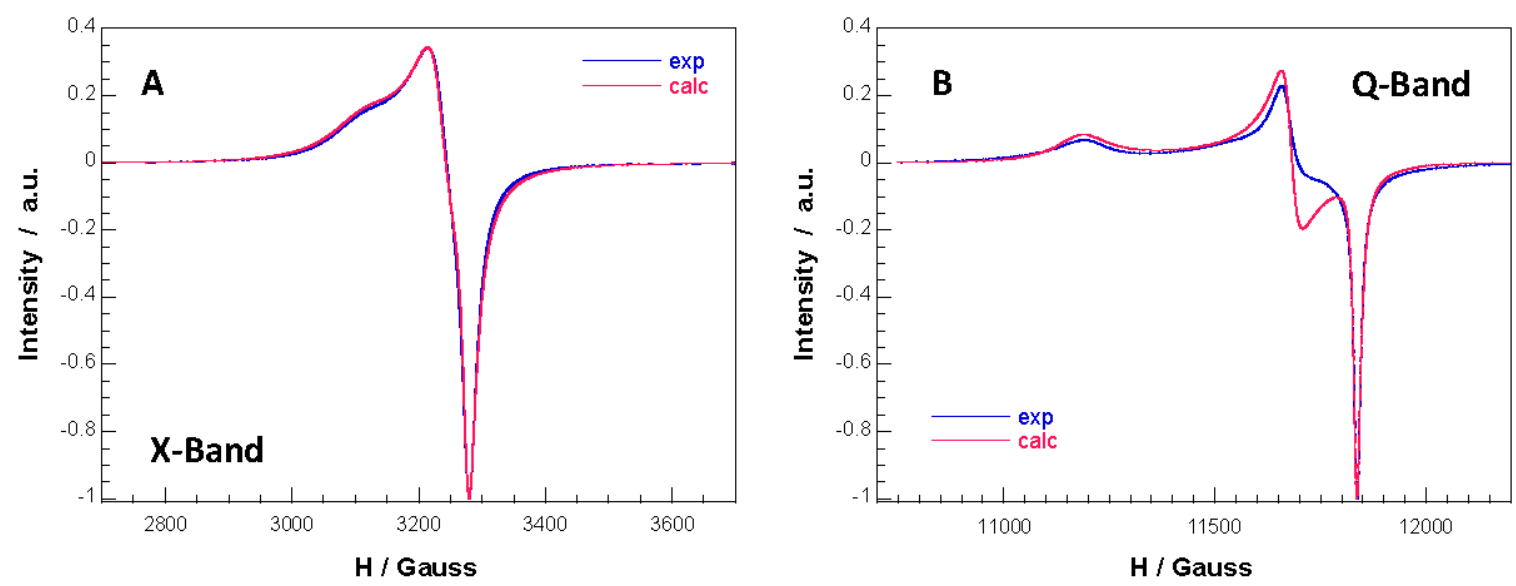

Figure 6. Experimental and calculated (a) X-band and (b) Q-band electron paramagnetic resonance (EPR) spectra of $\mathbf{1}$ at room temperature.

Table 5. Rhombic $g$ exchange tensors in $\mathbf{1}$ obtained from the fitting of the $\mathrm{X}$ - and Q-band EPR spectra.

\begin{tabular}{lcc}
\hline & X-Band & Q-Band \\
\hline$g_{1}$ & 2.159 & 2.168 \\
$g_{2}$ & 2.077 & 2.076 \\
$g_{3}$ & 2.049 & 2.048 \\
\hline
\end{tabular}

\section{Conclusions}

The study presented herein represents the first example of a POMOF-like compound based on polymeric molybdate units, namely, $[\mathrm{Cu}(\mathrm{cyclam})]_{2}\left[\mathrm{Mo}_{8} \mathrm{O}_{26}\right] \cdot 1.5 \mathrm{H}_{2} \mathrm{O}(\mathbf{1})$ that have been hydrothermally synthesized and chemically characterized. The open covalent three-dimensional framework of $\mathbf{1}$ is constituted by chains formed by $\gamma$-octamolybdate subunits, linked to each other through the $\{\mathrm{Cu}(\mathrm{cyclam})\}^{2+}$ complexes and displays structural voids that can be described as pockets communicated through narrow necks. The open framework of $\mathbf{1}$ remains virtually unaltered upon thermal evacuation of guest solvent molecules resulting in the anhydrous phase 1a with potentially accessible micropores as demonstrated by single-crystal X-ray diffraction. Therefore, we plan to take advantage of this feature to explore the applicability of this compound in the purification of mixtures of small molecules by selective capture. Currently, additional synthetic work is being carried out for the Mo/transition metal/cyclam system, the result of which will be reported elsewhere in due course.

Acknowledgments: This work was funded by UPV/EHU (Grant PPG17/37 and GIU17/050) and University of Tunis El Manar (predoctoral fellowship to N.D., including a three-month stay at Universidad del País Vasco, UPV/EHU). B.A. thanks UPV/EHU for a postdoctoral fellowship within the program "Convocatorias de Ayudas para la Especialización de Personal Investigador". Technical and human support provided by SGIker (UPV/EHU) is gratefully acknowledged.

Author Contributions: Nour Dissem prepared the title compound and performed its physicochemical characterization in close collaboration with Beñat Artetxe; Leire San Felices collected the single-crystal X-ray diffraction data and solved the structures; Luis Lezama was in charge of the EPR spectroscopy; Nour Dissem and Beñat Artetxe prepared the manuscript; Juan M. Gutiérrez-Zorrilla and Amor Haddad conceived the work and acted as scientific coordinators. 
Conflicts of Interest: The authors declare no conflict of interest.

\section{References}

1. Farrusseng, D. Metal-Organic Frameworks: Applications from Catalysis to Gas. Storage; Wiley-VCH Press: Weinheim, Germany, 2011.

2. Kitagawa, S.; Kitaura, R.; Noro, S. Functional porous coordination polymers. Angew. Chem. Int. Ed. 2004, 43, 2334-2375. [CrossRef] [PubMed]

3. Cote, A.P.; Benin, A.I.; Ockwig, N.W.; O'Keeffe, M.; Matzger, A.J.; Yaghi, O.M. Porous, crystalline, covalent organic frameworks. Science 2005, 310, 1166-1170. [CrossRef] [PubMed]

4. Zhou, H.-C.; Long, J.R.; Yaghi, O.M. Introduction to metal-organic frameworks. Chem. Rev. 2012, 112, 673-674. [CrossRef] [PubMed]

5. Feng, X.; Ding, X.S.; Jiang, D.L. Covalent organic frameworks. Chem. Soc. Rev. 2012, 41, 6010-6022. [CrossRef] [PubMed]

6. Maurin, G.; Serre, C.; Cooper, A.; Férey, G. The new age of MOFs and of their porous-related solids. Chem. Soc. Rev. 2017, 46, 3104-3107. [CrossRef] [PubMed]

7. Chughtai, A.H.; Ahmad, N.; Hussein, H.A.; Laypkovc, A.; Verpoort, F. Metal-organic frameworks: Versatile heterogeneous catalysts for efficient catalytic organic transformations. Chem. Soc. Rev. 2015, 44, 6804-6849. [CrossRef] [PubMed]

8. Huang, Y.-B.; Liang, J.; Wang, X.-S.; Cao, R. Multifunctional metal-organic framework catalysts: Synergistic catalysis and tandem reactions. Chem. Soc. Rev. 2017, 46, 126-157. [CrossRef] [PubMed]

9. Liu, R.; Yu, T.; Shi, Z.; Wang, Z. The preparation of metal-organic frameworks and their biomedical application. Int. J. Nanomed. 2016, 11, 1187-1200. [CrossRef] [PubMed]

10. Mínguez-Espallargas, G.; Coronado, E. Magnetic functionalities in MOFs: From the framework to the pore. Chem. Soc. Rev. 2018. [CrossRef] [PubMed]

11. Scott, H.S.; Ogiwara, N.; Chen, K.J.; Madden, D.G.; Pham, T.; Forrest, K.; Space, B.; Horike, S.; Perry, J.J., IV; Kitagawa, S.; et al. Crystal engineering of a family of hybrid ultramicroporous materials based upon interpenetration and dichromate linkers. Chem. Sci. 2016, 7, 5470-5476. [CrossRef]

12. Scott, H.S.; Bajpai, A.; Chen, K.J.; Pham, T.; Forrest, K.; Space, B.; Perry, J.J., IV; Zaworotko, M.J. Novel mode of 2-fold interpenetration observed in a primitive cubic network of formula [Ni(1,2-bis(4-pyridyl)acetylene $\left.)_{2}\left(\mathrm{Cr}_{2} \mathrm{O}_{7}\right)\right]_{\mathrm{n}}$. Chem. Commun. 2015, 51, 14832-14835. [CrossRef] [PubMed]

13. Mohamed, M.H.; Elsaidi, S.K.; Wojtas, L.; Pham, T.; Forrest, K.A.; Tudor, B.; Space, B.; Zaworotko, M.J. Highly selective $\mathrm{CO}_{2}$ uptake in uninodal 6-connected "mmo" nets based upon $\mathrm{MO}_{4}{ }^{2-}(\mathrm{M}=\mathrm{Cr}, \mathrm{Mo})$ pillars. J. Am. Chem. Soc. 2012, 134, 19556-19559. [CrossRef] [PubMed]

14. Pope, M.T. Heteropoly and Isopoly Oxometalates; Springer Press: Berlin, Germany, 1983.

15. Pope, M.T.; Müller, A. Polyoxometalates: From Platonic Solids to Anti-Retroviral Activity; Kluwer Press: Dordrecht, The Netherlands, 1994.

16. Sécheresse, F. Polyoxometalate Chemistry: Some Recent Trends; World Scientific Press: Singapore, 2013.

17. Miras, H.N.; Vilà-Nadal, L.; Cronin, L. Polyoxometalate based open-frameworks (POM-OFs). Chem. Soc. Rev. 2014, 43, 5679-5699. [CrossRef] [PubMed]

18. Du, D.-Y.; Qin, J.-S.; Li, S.-L.; Su, Z.-M.; Lan, Y.-Q. Recent advances in porous polyoxometalate-based metal-organic framework materials. Chem. Soc. Rev. 2014, 43, 4615-4632. [CrossRef] [PubMed]

19. Vilà-Nadal, L.; Cronin, L. Design and synthesis of polyoxometalate-framework materials from cluster precursors. Nat. Rev. Mater. 2017, 2, 17054. [CrossRef]

20. Uchida, S.; Mizuno, N. Design and syntheses of nano-structured ionic crystals with selective sorption properties. Coord. Chem. Rev. 2007, 251, 2537-2546. [CrossRef]

21. Uchida, S.; Hosono, R.; Eguchi, R.; Kawahara, R.; Osuga, R.; Kondo, J.N.; Hibino, M.; Mizuno, N. Proton conduction in alkali metal ion-exchanged porous ionic crystals. Phys. Chem. Chem. Phys. 2017, 19, 29077-29083. [CrossRef] [PubMed]

22. Zhang, Z.; Sadakane, M.; Noro, S.-I.; Murayama, T.; Kamachi, T.; Yoshisawa, K.; Ueda, W. Selective carbon dioxide adsorption of $\varepsilon$-Keggin-type zincomolybdate-based purely inorganic 3D frameworks. J. Mater. Chem. A 2015, 3, 746-755. [CrossRef] 
23. Boyd, T.; Mitchell, S.G.; Gabb, D.; Long, D.-L.; Song, Y.-F.; Cronin, L. POMzites: A family of zeolitic polyoxometalate frameworks from a minimal building block library. J. Am. Chem. Soc. 2017, 139, 5930-5938. [CrossRef] [PubMed]

24. Han, J.W.; Hill, C.L. A coordination network that catalyzes $\mathrm{O}_{2}$-based oxidations. J. Am. Chem. Soc. 2007, 129, 15094-15095. [CrossRef] [PubMed]

25. Li, X.-X.; Wang, Y.-X.; Wang, R.-H.; Cui, C.-Y.; Tian, C.-B.; Yang, G.-Y. Designed assembly of heterometallic cluster organic frameworks based on Anderson-type polyoxometalate clusters. Angew. Chem. Int. Ed. 2016, 55, 6462-6466. [CrossRef] [PubMed]

26. Zheng, S.-T.; Zhang, J.; Yang, G.-Y. Designed synthesis of POM-organic frameworks from $\left\{\mathrm{Ni}_{6} \mathrm{PW}_{9}\right\}$ building blocks under hydrothermal conditions. Angew. Chem. Int. Ed. 2008, 47, 3909-3913. [CrossRef] [PubMed]

27. Qin, J.-S.; Du, D.-Y.; Guan, W.; Bo, X.-J.; Li, Y.-F.; Guo, L.-P.; Su, Z.-M.; Wang, Y.-Y.; Lan, Y.-Q.; Zhou, H.-C. Ultrastable polymolybdate-based metal-organic frameworks as highly active electrocatalysts for hydrogen generation from water. J. Am. Chem. Soc. 2015, 137, 7169-7177. [CrossRef] [PubMed]

28. Martín-Caballero, J.; Wéry, A.S.J.; Reinoso, S.; Artetxe, B.; San Felices, L.; El Bakkali, B.; Trautwein, G.; Alcañiz-Monge, J.; Vilas, J.L.; Gutiérrez-Zorrilla, J.M. A robust open framework formed by decavanadate clusters and copper(II) complexes of macrocyclic polyamines: Permanent microporosity and catalytic oxidation of cycloalkanes. Inorg. Chem. 2016, 55, 4970-4979. [CrossRef] [PubMed]

29. Martín-Caballero, J.; Wéry, A.S.J.; Artetxe, B.; Reinoso, S.; San Felices, L.; Vilas, J.L.; Gutiérrez-Zorrilla, J.M. Sequential single-crystal-to-single-crystal transformations promoted by gradual thermal dehydration in a porous metavanadate hybrid. CrystEngComm 2015, 17, 8915-8925. [CrossRef]

30. Martín-Caballero, J.; Artetxe, B.; Reinoso, S.; San Felices, L.; Castillo, O.; Beobide, G.; Vilas, J.L.; Gutiérrez-Zorrilla, J.M. Thermally-triggered crystal dynamics and permanent porosity in the first heptatungstate-metalorganic three-dimensional hybrid framework. Chem. Eur. J. 2017, 23, 14962-14974. [CrossRef] [PubMed]

31. Reinoso, S.; Artetxe, B.; San Felices, L.; Gutiérrez-Zorrilla, J.M. Single-crystal-to-single-crystal transformations in stimuli responsive compounds based on polyoxometalate clusters. In Polyoxometalates: Properties, Structure and Synthesis; Roberts, A.P., Ed.; Nova Science Press: Hauppauge, NY, USA, 2016; pp. 143-212.

32. Müller, A.; Krickemeyer, E.; Meyer, J.; Bögge, H.M.; Peters, F.; Plass, W.; Diemann, E.; Dillinger, S.; Nonnenbruch, F.; Randerath, M.; Menke, C. $\left[\mathrm{Mo}_{154}(\mathrm{NO})_{14} \mathrm{O}_{420}(\mathrm{OH})_{28}\left(\mathrm{H}_{2} \mathrm{O}\right)_{70}\right]^{(25 \pm 5)-}$ : A water-soluble big wheel with more than 700 atoms and a relative molecular mass of about 24000. Angew. Chem. Int. Ed. Engl. 1995, 34, 2122-2124. [CrossRef]

33. Müller, A.; Krickemeyer, E.; Bögge, H.; Schmidtmann, M.; Peters, F. Organizational forms of matter: An inorganic super fullerene and keplerate based on molybdenum oxide. Angew. Chem. Int. Ed. 1998, 37, 3359-3363. [CrossRef]

34. Müller, A.; Beckmann, E.; Bögge, H.; Schmidtmann, M.; Dress, A. Inorganic chemistry goes protein size: A mo368 nano-hedgehog initiating nanochemistry by symmetry breaking. Angew. Chem. Int. Ed. 2002, 41, 1132-1167. [CrossRef]

35. Blazevic, A.; Rompel, A. The Anderson-Evans polyoxometalate: From inorganic building blocks via hybrid organic-inorganic structures to tomorrows "Bio-POM". Coord. Chem. Rev. 2016, 307, 42-64. [CrossRef]

36. Wang, Y.; Pan, S.; Yu, H.; Su, X.; Zhang, M.; Zhang, F.; Han, J. Cs ${ }_{4} \mathrm{Mo}_{5} \mathrm{P}_{2} \mathrm{O}_{22}$ : A first Strandberg-type POM with 1D straight chains of polymerized $\left[\mathrm{Mo}_{5} \mathrm{P}_{2} \mathrm{O}_{23}\right]^{6-}$ units and moderate second harmonic generation response. Chem. Commun. 2013, 49, 306-308. [CrossRef] [PubMed]

37. CrysAlisPro. Software System, Version 171.37.34; Agilent Technologies UK, Ltd.: Oxford, UK, 2012.

38. Dolomanov, O.V.; Bourhis, L.J.; Gildea, R.J.; Howard, J.A.; Puschmann, H.J. Olex2-A complete package for Molecular Crystallography. J. Appl. Crystallogr. 2009, 42, 339-342. [CrossRef]

39. Sheldrick, G.M. A short history of SHELX. Acta Crystallogr. 2008, 64, 112-122. [CrossRef] [PubMed]

40. Spek, A.L. Structure validation in chemical crystallography. Acta Crystallogr. 2009, 65, 148-155. [CrossRef] [PubMed]

41. Farrugia, L.J. WinGX Program Features. J. Appl. Crystallogr. 1999, 32, 837-838. [CrossRef]

42. Brown, I.D.; Alternatt, D. Bond-Valence Parameters obtained from a systematic analysis of the inorganic crystal structure database. Acta Crystallogr. 1985, 41, 244-247. [CrossRef]

43. Llunell, M.; Casanova, D.; Cirera, J.; Bofill, J.M.; Alemany, P.; Alvarez, S.; Pinsky, M.; Avnir, D. SHAPE v1.1b; Universitat de Barcelona: Barcelona, Spain; The Hebrew University of Jerusalem: Jerusalem, Israel, 2005. 
44. Kihlborg, L. Least squares refinement of the crystal structure of molybdenum trioxide. Ark. Kemi 1963, 21, 357-364.

45. Nassau, K.; Abrahams, S.C. The growth and properties of single crystal cupric molybdate. J. Cryst. Growth 1968, 2, 136-140. [CrossRef]

46. Bridgeman, A.J. The electronic structure and stability of the isomers of octamolybdate. J. Phys. Chem. A 2002, 106, 12151-12160. [CrossRef]

47. Xiao, D.; Hou, Y.; Wang, E.; Wang, S.; Li, Y.; Xu, L.; Hu, C. Hydrothermal synthesis and characterization of an unprecedented $\eta$-type octamolybdate: $\left[\left\{\mathrm{Ni}(\mathrm{phen})_{2}\right\}_{2}\left(\mathrm{Mo}_{8} \mathrm{O}_{26}\right)\right]$. Inorg. Chim. Acta 2004, 357, 2525-2531. [CrossRef]

48. Allis, D.G.; Burkholder, E.; Zubieta, J. A new octamolybdate: Observation of the $\theta$-isomer in $\left[\mathrm{Fe}(\operatorname{tpyprz})_{2}\right]_{2}$ $\left[\mathrm{Mo}_{8} \mathrm{O}_{26}\right] \cdot 3.7 \mathrm{H}_{2} \mathrm{O}$ (tpyprz $\frac{1}{4}$ tetra-2-pyridylpyrazine). Polyhedron 2004, 23, 1145-1152. [CrossRef]

49. Yue, Z.-C.; Du, H.-J.; Niu, Y.-Y.; Jin, G.-X. An unprecedented เ-type octamolybdate: $\left[\mathrm{TbI}_{1}\right]_{2}\left[\left(\beta-\mathrm{Mo}_{8} \mathrm{O}_{26}\right)_{0.5}\right.$ $\left(\mathrm{t}-\mathrm{Mo}_{8} \mathrm{O}_{26}\right)$ ] directed by a new tricationic template. CrystEngComm 2013, 15, 9844-9848. [CrossRef]

50. Wang, L.; Yin, P.; Zhang, J.; Hao, J.; Lv, C.; Xiao, F.; Wei, Y. $\chi$-Octamolybdate $\left[\mathrm{Mo}_{4}{ }_{4} \mathrm{Mo}^{\mathrm{VI}}{ }_{4} \mathrm{O}_{24}\right]^{4-}$ : An unusual small polyoxometalate in partially reduced form from nonaqueous solvent reduction. Chem. Eur. J. 2011, 17, 4796-4801. [CrossRef] [PubMed]

51. McCarron, E.M., III; Harlow, R.L. The synthesis and structure of tetrasodium tetramethoxyoctamolybdate-methanol complex $\left(\mathrm{Na}_{4}\left[\mathrm{Mo}_{8} \mathrm{O}_{24}\left(\mathrm{OCH}_{3}\right)_{4}\right] .8 \mathrm{MeOH}\right)$ : A novel isopolymolybdate that decomposes with the loss of formaldehyde. J. Am. Chem. Soc. 1983, 105, 6179-6181. [CrossRef]

52. Ito, T.; Mikurube, K.; Hasegawa, K.; Matsumoto, T.; Kosaka, K.; Naruke, H.; Koguchi, S. Structural variation in polyoxomolybdate hybrid crystals comprising ionic-liquid surfactants. Crystals 2014, 4, 42-52. [CrossRef]

53. Coué, V.; Dessapt, R.; Bujoli-Doeuff, M.; Evain, M.; Jobic, S. Synthesis, characterization and photochromic properties of hybrid organic-inorganic materials based on molybdate, DABCO, and pyperazine. Inorg. Chem. 2007, 46, 2824-2835. [CrossRef] [PubMed]

54. Groom, C.R.; Bruno, I.J.; Lightfoot, M.P.; Ward, S.C. The Cambridge Structural Database. Acta Crystallogr. 2016, 72, 171-179. [CrossRef] [PubMed]

55. Yue, Z.-C.; Shen, L.-X.; Wu, H.-H.; Li, X.-H.; Niu, Y.-Y. pH-dependent assembly of metal-organic hybrid compounds based on octamolybdates and a new flexible multidentate ligand. CrystEngComm 2013, 15, 9938-9948. [CrossRef]

56. Zhai, Q.-G.; Wu, X.-Y.; Chen, S.-M.; Zhao, Z.-G.; Lu, C.-Z. Construction of Ag/1,2,4-triazole/ polyoxometalates hybrid family varying from diverse supramolecular assemblies to 3-D rod-packing framework. Inorg. Chem. 2007, 46, 5046-5058. [CrossRef] [PubMed]

57. Liu, H.-Y.; Wu, H.; Yang, J.; Liu, Y.-Y.; Liu, B.; Liu, Y.-Y.; Ma, J.F. pH-Dependent assembly of 1D to $3 \mathrm{D}$ octamolybdate hybrid materials based on a new flexible bis-[(pyridyl)-benzimidazole] ligand. Cryst. Growth Des. 2011, 11, 2920-2927. [CrossRef]

58. Wang, X.; Sun, J.; Lin, H.; Chang, Z.; Wang, X.; Liu, G. A series of Anderson-type polyoxometalate-based metal-organic complexes: Their $\mathrm{pH}$-dependent electrochemical behaviour, and as electrocatalysts and photocatalysts. Dalton Trans. 2016, 45, 12465-12478. [CrossRef] [PubMed]

59. Du, H.-J.; Shu, Z.-Z.; Niu, Y.-Y.; Song, L.-S.; Zhu, Y. Unprecedented polymeric $1 / \infty\left[\mathrm{Mo}_{8} \mathrm{O}_{26}\right]^{4-}$ chains and four novel organic-inorganic hybrids based on Mo-POMs and azaheterocycles templates. J. Solid State Chem. 2012, 190, 296-302. [CrossRef]

60. Hubbard, D.J.; Johnston, A.R.; Casalongue, H.S.; Sarjeant, A.N.; Norquist, A.J. Synthetic approaches for noncentrosymmetric molybdates. Inorg. Chem. 2008, 47, 8518-8525. [CrossRef] [PubMed]

61. Thorn, K.J.; Sarjeant, A.N.; Norquist, A.J. $\left(\mathrm{C}_{4} \mathrm{H}_{14} \mathrm{~N}_{2}\right)_{2}\left[\mathrm{Mo}_{8} \mathrm{O}_{26}\right] \cdot 2 \mathrm{H}_{2} \mathrm{O}$ : A new octamolybdate salt. Acta Crystallogr. 2005, 61, m1665-m1667.

62. Casalongue, H.S.; Choyke, S.J.; Sarjeant, A.N.; Schrier, J.; Norquist, A.J. Charge density matching in templated molybdates. J. Solid State Chem. 2009, 182, 1297-1303. [CrossRef]

63. Zhang, H.-Y.; Tan, K.; Guan, W.; Li, S.-L.; Yang, G.-S.; Shao, K.-Z.; Yan, L.-K.; Su, S.-M. Inorganic-organic hybrid compounds based on the co-existence of different isomers or forms of polymolybdate. CrystEngComm 2010, 12, 3684-3690. [CrossRef]

64. Evain, M.; Petricek, V.; Coué, V.; Dessapt, R.; Bujoli-Doeuff, M.; Jobic, S. Commensurate $\left(\mathrm{C}_{6} \mathrm{H}_{14} \mathrm{~N}_{2}\right)_{2}\left[\mathrm{Mo}_{8} \mathrm{O}_{26}\right] \cdot 4 \mathrm{H}_{2} \mathrm{O}$ and incommensurate $\left(\mathrm{C}_{6} \mathrm{H}_{14} \mathrm{~N}_{2}\right)_{2}\left[\mathrm{Mo}_{8} \mathrm{O}_{26}\right] \cdot 4.66 \mathrm{H}_{2} \mathrm{O}$ : A structural versatility linked to solvent content. Acta Crystallogr. 2006, 62, 790-797. [CrossRef] [PubMed] 
65. Bosnich, B.; Poon, C.K.; Tobe, M.L. Complexes of cobalt(III) with a cyclic tetradentate secondary amine. Inorg. Chem. 1965, 4, 1102-1108. [CrossRef]

66. Bakaj, M.; Zimmer, M. Conformational analysis of copper(II) 1,4,8,11-tetraazacyclotetradecane macrocyclic systems. J. Mol. Struct. 1999, 508, 59-72. [CrossRef]

67. Iturrospe, A.; Artetxe, B.; Reinoso, S.; San Felices, L.; Vitoria, P.; Lezama, L.; Gutiérrez-Zorrilla, J.M. Copper(II) complexes of tetradentate pyridil ligands supported on Keggin polyoxometalates: Single-crystal to single-crystal transformations promoted by reversible dehydration processes. Inorg. Chem. 2013, 52, 3084-3093. [CrossRef] [PubMed]

68. Hathaway, B.J. A New Look at the stereochemistry and electronic properties of complexes of the copper(II) ion. Struct. Bonding 1984, 57, 55-118.

(C) 2018 by the authors. Licensee MDPI, Basel, Switzerland. This article is an open access article distributed under the terms and conditions of the Creative Commons Attribution (CC BY) license (http:/ / creativecommons.org/licenses/by/4.0/). 